\title{
Processes of stroke unit care and outcomes at discharge in Vietnam: findings from the REgistry of Stroke care Quality (RES-Q) in a major public hospital
}

\section{Background}

Stroke is a leading cause of global disease burden. ${ }^{1}$ The burden of stroke is considerable in lowmiddle income countries (LMICs) accounting for 52\% of prevalent strokes, $71 \%$ stroke-related deaths, and $78 \%$ of disability-adjusted life years lost, globally. ${ }^{2}$ LMICs experience up to $23 \%$ greater incidence of stroke than high-income countries (HICs), and the gap continues to widen. ${ }^{2}$ In HICs, the burden of stroke is related to the aging population while in LMICs, stroke occurs in younger ages mostly due to the greater prevalence of cardiovascular disease risk factors. ${ }^{3}$

Stroke is the leading cause of death, and the leading cause of years of life lost in Vietnam. ${ }^{4}$ Over 20 years, the incidence of stroke in Vietnam has increased from $213.58 / 100,000$ person-years in 1990 to $254.78 / 100,000$ person-years in $2010 .^{2}$ More than 200,000 people have a new stroke each year, leading to 11,000 deaths nationwide..$^{5}$ In the 2013 Global Burden of Disease Study, the proportion of stroke-related mortality in Vietnam accounted for $32 \%$ of total deaths and was at the upper end of the global range (from $2 \%$ in Papua to $35 \%$ in Macedonia). ${ }^{6}$ It is estimated that 1.5 million people in Vietnam (1.6\% of the population; 2013$)$ are living with the consequences of stroke. ${ }^{7}$

One of the greatest opportunities to reduce preventable death and disability after stroke is to ensure access to evidence-based treatment as recommended in clinical guidelines, such as the use of intravenous thrombolysis and prevention medication for risk factors. ${ }^{8}$ Stroke clinical registries that incorporate standardized methods of data collection for processes of hospital care as well as 
associated outcomes after stroke offer reliable guidance on how to reduce the impact of stroke. ${ }^{9}$ In Vietnam, systematic and standardized routine collection of outcome data to provide evidence of adherence to clinical guideline recommendations for stroke is unavailable. ${ }^{10}$

Our aims were to examine the processes of evidence-based care in hospital and outcomes at discharge among patients with acute first-ever stroke, and describe the factors associated with these outcomes from a major public hospital in Vietnam that admits approximately 15,000 strokes per year.

\section{Methods}

In this study, we included hospitalized patients with first-ever strokes (not including transient ischemic stroke) admitted between June 2017 and July 2018 to the stroke unit within the 115 People's Hospital - a major public hospital in Vietnam. This is a prospective observational study whereby standardized methods of data collection for processes of hospital care and outcomes were collected using the REgistry of Stroke Care Quality (RES-Q) system (see https://esostroke.org/res-q/). The RES-Q is a data collection tool of the European Stroke Organization Enhancing and Accelerating Stroke Treatment (ESO-EAST) Project, a program to improve the stroke care system (see https://www.qualityregistry.eu/).

\section{Study factors}

A wide range of factors was recorded in the RES-Q registry, including patient characteristics and care received in hospital. ${ }^{11}$ The factors investigated in the study included (1) sociodemographics: age, sex; (2) health behaviors/comorbidities: presence of atrial fibrillation, smoking status; (3) stroke-related factors: stroke severity assessed by the National Institutes of Health Stroke Scale (NIHSS), stroke type, in-hospital stroke (stroke occurred during an episode 
of admitted patient care for a different condition), time from stroke onset to hospital arrival, and door-to-needle time for intravenous thrombolysis; (4) discharge information: length of hospital stay and discharge destination; and (5) evidence-based processes of care provided while in hospital. The obtained information on hospital care included level-1 evidence-based processes of care according to clinical guidelines: ${ }^{12,13}$

\section{Outcome measurement}

In-hospital mortality was obtained from the patient medical records. Functional outcome at discharge was indicated by the ability to walk 10 meters without assistance at time of discharge.

\section{Statistical analysis}

Statistical analyses were performed using Stata 12.1 (StataCorp Texas, 2011).${ }^{14}$ All two-tailed pvalues $\leq 0.05$ were considered statistically significant.

We examined the differences in patient characteristics, processes of care, and outcomes using the $\chi 2$ test for categorical variables (e.g. stroke type) and $t$ test or Wilcoxon signed-rank sum test, as appropriate for continuous variables (e.g. age, NIHSS score). Some medication restrictions may be appropriate given contraindications or to meet treatment guidelines. ${ }^{13} \mathrm{We}$ assumed that those presenting at hospital $\leq 3.5$ hours of stroke onset needed about one additional hour for decision processes to occur to be eligible for thrombolysis treatment 4.5 hours window after acute IS). ${ }^{15}$ Missing data on processes of care were coded as not receiving the corresponding therapy.

We investigated factors that contributed to in-hospital mortality and functional outcome at discharge in log-binomial regression models using purposeful model building. ${ }^{16}$ The modelbuilding process was initially undertaken for each variable separately and then adjustments for all significant contributing factors $(\mathrm{p}<0.05)$ were examined in multivariable models. 


\section{Results}

Patient characteristics

There was a total of 6,601 first-ever participants with stroke; with $44 \%$ being females (Table 1). The median age was 62 years (interquartile range; IQR 53-72), and women generally were about 5 years older than men (median age 65 , IQR $56-75$ vs men 60 , IQR 52-69; $<<0.001$ ). More than two-fifths of the patients $(42.1 \% ; \mathrm{n}=2,779)$ were current smokers, and the proportion was four times greater in men compared to women $(62.9 \%$ vs $15.7 \%$; $<<0,001)$. We detected 630 patients with evidence of atrial fibrillation (86.4\%) among 729 cases that were screened for atrial fibrillation.

\section{Stroke severity and stroke type}

The median NIHSS score was 7 points (IQR 4-12). There were 569 cases (8.8\%) presenting with loss of consciousness (drowsy or comatose) at admission. There were only $34(0.5 \%)$ strokes that occurred while in the hospital. The majority of patients were found to have IS (79.9\%), followed by ICH (18.4\%) while only a very small proportion had SAH (1.7\%).

\section{Processes of care}

The median time from stroke onset to hospital arrival was 15.7 hours (IQR 5.6-37.5) and only $12 \%$ of all hospitalized patients with stroke were admitted to hospital $\leq 3.5$ hours (Table 1 ).

Almost all hospitalized patients with stroke received neuroimaging (98.6\%). Among those with IS, 257 (4.9\%) received carotid investigation $\leq 7$ days after hospital admission. Carotid endarterectomy or angioplasty/stenting $\leq 2$ weeks after stroke onset were performed among 30 out of $345(8.7 \%)$ of the patients with IS eligible for the procedures. 
Of all patients admitted to the hospital with IS, 9.4\% $(n=497)$ were treated with intravenous thrombolytic therapy and they were all admitted to hospital $\leq 3.5$ hours. Up to $11.6 \%(n=611)$ of IS cases underwent a recanalization procedure, including intravenous thrombolysis alone $(n=377)$, endovascular treatment alone $(n=114)$, or both $(n=120)$. The median door-to-needle time for intravenous thrombolysis was 45 minutes (IQR 33-60).

Approximately one-third of the participants (32.8\%) had assessment for rehabilitation needs $\leq 72$ hours after hospital admission. Of those with $\mathrm{ICH}$, surgical evacuation of the hematoma was performed among 17 cases (1.4\%) and hemicraniectomy was used in 30 cases $(8.7 \%)$. Almost all patients with stroke (99.5\%) received dysphagia assessment/screening. In general, more than $90 \%$ of patients received secondary prevention therapies that were level-1 evidence-based processes of care: hypertensive agents (92.2\%), cholesterol-lowering medication (IS; 99.0\%), antithrombotic medication (IS; 97.9\%).

The median length of hospital stay was 3 days (IQR 1-6) among those deceased within hospital and 4 days (IQR 3-6) for survivors at discharge. Of all cases, 88.9\% were discharged home while only $3.1 \%(n=199)$ died. The remaining cases were either transferred to another hospital $(2.0 \%)$, rehabilitation centers $(5.1 \%)$, or long-term care facility/nursing home (1.0\%). At discharge, nearly half $(45.8 \% ; n=2,931)$ of the survivors were able to walk 10 meters without assistance (Table 1). In multivariable models, more advanced age and severe strokes were contributing factors to mortality and poorer functional outcome at discharge. Being administered with antihypertensive agents was negatively associated with poorer outcomes after stroke (Table 2). In addition, the provision of cholesterol-lowering and antithrombotic medications was found to be significantly associated with better survival among those with IS (Table 2). There was no evidence of statistical interactions between covariates and the investigated outcomes. 
The evidence-based care performances and discharge outcome varied across our study and some selected reports in national stroke registries in other LMICs (Table 3).

\section{Discussion}

The proportion of patients with IS receiving thrombolysis therapy has substantially increased from $0.6 \%$ in $2006,3.2 \%$ in 2016 (unpublished data from the 115 's People Hospital) to $9.4 \%$ in the present study, demonstrating the effort to improve the quality of stroke care at this hospital. This thrombolysis rate is greater than that of some selected stroke registries in LMICs (e.g. Thai Stroke Registry: $3.8 \%,{ }^{17}$ Taiwan Stroke Registry: $8.8 \%{ }^{18}$ ). However, the considerable delay in the time from stroke onset to hospital arrival remains an important issue. More than $70 \%$ of those with stroke admitted to our stroke unit did not arrive $\leq 3.5$ hours after experiencing stroke symptoms and they were then potentially ineligible for intravenous thrombolysis therapy. Within Vietnam, public misconceptions of stroke and use of inappropriate traditional therapies (e.g. coin rubbing) may contribute to delays in seeking acute stroke care in hospitals, limiting the options for evidence-based treatments. ${ }^{10}$ The median door-to-needle time at the hospital, which has reduced to 45 minutes, achieved the initial goal recommended by the American Heart Association/American Stroke Association's target $(\leq 60$ minutes for at least $50 \%$ of acute IS patients). ${ }^{19}$ Our ultimate aim should be to continue to improve the door-to-needle times of $\leq 60$ minutes for all IS, as recommended in current clinical guidelines. ${ }^{12}$ Some aspects of care including assessment for rehabilitation needs and carotid investigation appeared to be more sub-optimal when compared to other LMICs (Table 3). This suggests a need for better understanding of the local barriers and enablers to improving the quality of care in this hospital and among other hospitals in Vietnam. For example, according to the China Stroke Registry II, ${ }^{20}$ the reasons for lack of assessment for rehabilitation needs $\leq 72$ hours after hospital 
admission included the patients' condition that did not allow for assessment, patients/relative's refusal, and lack of personnel and equipment.

\section{Outcomes at discharge}

In the current study, in-hospital mortality was at $3.1 \%$, similar to the findings from the previous hospital-based cohort at the 115 People's Hospital $(3.1 \% ; 2010)^{21}$ and a population-based at a provincial hospital in Da Nang City, South-central Vietnam $\left(3.3 \%\right.$; 2010). ${ }^{22}$ The mortality is comparable to that of some national stroke registries in LMICs including Thai Stroke Registry $(3.2 \%)^{17}$ and Taiwan Stroke Registry $(4.0 \%)^{18}$ but lower than the figure in Bahrain $(13.4 \%)^{23}$ and Malaysia $^{24}(11.1 \%$; Table 3$)$. The low mortality rate is likely due to the short length of hospital stay (median: 4 days) and many hospitalized patients may go home to die. In a previous study conducted in our ward (2009-2010), the average total costs per stroke admission presented in United States (US) dollars were US\$963 (including US\$560 for direct medical cost). ${ }^{25}$ Health insurance only covered about half of the direct medical costs and the total costs of stroke were 2.38 times greater than the median household income of the respondents in this study. ${ }^{25}$ The long-term financial impact on families is of concern. Many stroke survivors are reliant on family members, many of whom are women (77\%), for ongoing care ${ }^{25}$ and is partly because post-stroke rehabilitation services are extremely limited and costly ${ }^{26}$ With the increasing numbers of stroke in Vietnam, ${ }^{27}$ and the high-cost burden of treatment, it is important to implement effective treatment strategies to reduce the impact of this disease.

We found that processes of care including antihypertensive, cholesterol-lowering and antithrombotic medication were associated with better survival and functional outcome. This 
could be translated that if the hospital could maximize their processes of care, the impact of stroke would be reduced. Apart from processes of care, age and stroke severity were found to be major predictors of in-hospital mortality and functional outcome. In the present study, stroke occured in younger age (approximately 10 years younger) compared to those in HICs. This is

mostly due to the increased cardiovasular disease risk factors among adults. ${ }^{3}$ The rate of smoking in men is very high compared to that in western countries. ${ }^{28}$ In this registry, data on other risk factors for stroke (such as hypertension, diabetes) were not available, but evidence suggests that many people in Vietnam have uncontrolled hypertension, obesity, diabetes and unhealthy diet. ${ }^{7}$ This emphasizes the importance to better manage cardiovascular risk factors such as high blood pressure, diabetes, or unhealthy behaviors (e.g. smoking, lack of exercise, unhealthy diets) in the general population to reduce the burden of stroke. Also, it is imperative to ensure access to evidence-based care for all people with stroke to lessen stroke severity and improve outcomes after stroke.

\section{Further recommendations}

There are currently about 1,500 hospitals across Vietnam. ${ }^{29}$ There are limited resources and infrastructure for stroke care and treatment, including shortage of staff with expertise in stroke or who are upskilled to manage stroke according to best-practice in hospitals. ${ }^{29}$ Only fewer than 10 stroke units are available to service a population of more than 80 million, ${ }^{10}$ suggesting that the vast majority of patients may not receive adequate evidence-based care. Therefore, there is an urgent need for more stroke units and improved management of stroke as a medical emergency and greater provision of specialized care across the country.

\section{Strengths and limitations}


The analyses are based on a large dataset from a 13-month surveillance of 6,601 first-ever strokes admitted to the stroke unit of a major public hospital. Our results from high-quality data collected through the RES-Q platform, which is used in more than 50 countries, ${ }^{30}$ will help inform future interventions to ensure systematic monitoring of the quality of stroke care and patient outcomes in Vietnam, which can guide policy and practice decisions. Since early 2017, Vietnam has contributed the greatest number of patients registered in the RES-Q central system $\left(\mathrm{n}=13,818 ; 8\right.$ Vietnamese hospitals). ${ }^{31}$ There has been an increasing interest in using RES-Q for stroke registration in hospitals all over the world, and some preliminary findings have been presented as conference abstracts..$^{32,33}$

The 115 People's Hospital is unique in Vietnam to have leading stroke specialists, and a Stroke Unit. ${ }^{34}$ This can be seen in our study findings that, in our stroke unit, thrombolytic or endovascular therapy for acute IS had been undertaken for more than one case per day over the 13 months. Other limitations include that we were unable to track the survival status if a patient chose to die at home. Barriers to RES-Q included the inability to collect data on comorbidities (i.e. hypertension, diabetes), and patient outcomes after stroke beyond hospital (i.e. 90 days) and in the long term. Because of the cultural preferences for end-of-life care at home in Vietnam, ${ }^{21}$ the mortality rate $(3.1 \%)$ in this study is likely underestimated. Linkage of stroke incidence studies to the national death registrations offers a solution for the lack of long-term survival information in many HICs. ${ }^{35}$ However, national registration systems for deaths remain uncommon in most $\mathrm{LMICs}^{36}$ including Vietnam.

\section{Conclusion}

In our study, the considerable delay in the time from stroke onset to hospital arrival is of concern, suggesting an essential call for better strategies to increase public awareness for stroke 
in Vietnam. Most hospitalized patients with acute stroke in the stroke unit within 115 People's Hospital received evidence-based care and have favorable outcomes. To achieve the favourable outcomes shown in the major public hospital, more stroke units and greater provision of specialized care across Vietnam and other LMICs are crucial.

\section{Abbreviations}

RES-Q: Registry of Stroke Care Quality. IS: ischemic stroke.

\section{References}

1. Feigin VL, Krishnamurthi RV, Parmar P, Norrving B, Mensah GA, Bennett DA, BarkerCollo S, Moran AE, Sacco RL, Truelsen T, Davis S, Pandian JD, Naghavi M, Forouzanfar MH, Nguyen G, Johnson CO, Vos T, Meretoja A, Murray CJ, Roth GA, Group GBDW, Group GBDSPE. Update on the Global Burden of Ischemic and Hemorrhagic Stroke in 1990-2013: The GBD 2013 Study. Neuroepidemiology. 2015;45(3):161-76.

2. Feigin VL, Forouzanfar MH, Krishnamurthi R, Mensah GA, Connor M, Bennett DA, Moran AE, Sacco RL, Anderson L, Truelsen T, O'Donnell M, Venketasubramanian N, Barker-Collo S, Lawes CM, Wang W, Shinohara Y, Witt E, Ezzati M, Naghavi M, Murray C. Global and regional burden of stroke during 1990-2010: findings from the Global Burden of Disease Study 2010. Lancet. 2014 Jan 18;383(9913):245-54.

3. Putaala J. Ischemic stroke in the young: current perspectives on incidence, risk factors, and cardiovascular prognosis. European Stroke Journal. 2016 2016/03/01 [cited 2018/06/01];1(1):2840.

4. Nhung NT, Long TK, Linh BN, Vos T, Huong NT, Anh ND. Estimation of Vietnam national burden of disease 2008. Asia Pac J Public Health. 2014 Sep;26(5):527-35. 
5. Islam SM, Purnat TD, Phuong NT, Mwingira U, Schacht K, Froschl G. Non-communicable diseases (NCDs) in developing countries: a symposium report. Global Health. 2014 Dec $11 ; 10: 81$.

6. Feigin VL, Norrving B, Mensah GA. Global Burden of Stroke. Circulation Research [10.1161/CIRCRESAHA.116.308413]. 2017;120(3):439.

7. Le TH, Duong TP, Le TT, Nguyen TL, Pham TD. Prevalence of stroke in 8 provinces representing 8 ecoregions of vietnam 2013 - 2014 and related factors. Vietnamese Journal of Medical Research 2016;104(6).

8. Cadilhac DA, Andrew NE, Stroil Salama E, Hill K, Middleton S, Horton E, Meade I, Kuhle S, Nelson MR, Grimley R, Australian Stroke Clinical Registry C. Improving discharge care: the potential of a new organisational intervention to improve discharge after hospitalisation for acute stroke, a controlled before-after pilot study. BMJ Open. 2017 Aug 4;7(8):e016010.

9. Cadilhac DA, Kim J, Lannin NA, Kapral MK, Schwamm LH, Dennis MS, Norrving B, Meretoja A. National stroke registries for monitoring and improving the quality of hospital care: A systematic review. Int J Stroke. 2016 Jan;11(1):28-40.

10. Nguyen Huu C. Stroke Care in Vietnam. International Journal of Stroke. 2007 2007/11/01 [cited 2018/01/04];2(4):279-280.

11. Norrving B, Bray BD, Asplund K, Heuschmann P, Langhorne P, Rudd AG, Wagner M, Wiedmann S, Wolfe CD. Cross-National Key Performance Measures of the Quality of Acute Stroke Care in Western Europe. Stroke. 2015 Oct;46(10):2891-5.

12. Powers WJ, Rabinstein AA, Ackerson T, Adeoye OM, Bambakidis NC, Becker K, Biller J, Brown M, Demaerschalk BM, Hoh B, Jauch EC, Kidwell CS, Leslie-Mazwi TM, Ovbiagele B, Scott PA, Sheth KN, Southerland AM, Summers DV, Tirschwell DL. 2018 Guidelines for the 
early management of patients with acute Ischemic stroke: A guideline for healthcare professionals from the American Heart Association/American Stroke Association. Stroke [10.1161/STR.0000000000000158]. 2018.

13. National Stroke Foundation. Clinical guidelines for stroke management 2010. Melbourne, Australia; 2010.

14. StataCorp. Stata Statistical Software: Release 12; 2011.

15. Phan HT, Gall SL, Blizzard CL, Lannin NA, Thrift AG, Anderson CS, Kim J, Grimley R, Castley HC, Hand P, Cadilhac DA. Sex Differences in Care and Long-Term Mortality After Stroke: Australian Stroke Clinical Registry. Journal of Women's Health [10.1089/jwh.2018.7171]. 2019 [cited 2019/03/27];(in press).

16. Greenland S. Modeling and variable selection in epidemiologic analysis. American Journal of Public Health. 1989;79(3):340-349.

17. Nilanont Y, Nidhinandana S, Suwanwela NC, Hanchaiphiboolkul S, Pimpak T, Tatsanavivat P, Saposnik G, Poungvarin N. Quality of acute ischemic stroke care in Thailand: a prospective multicenter countrywide cohort study. J Stroke Cerebrovasc Dis. 2014 Feb;23(2):213-9.

18. Hsieh FI, Lien LM, Chen ST, Bai CH, Sun MC, Tseng HP, Chen YW, Chen CH, Jeng JS, Tsai SY, Lin HJ, Liu CH, Lo YK, Chen HJ, Chiu HC, Lai ML, Lin RT, Sun MH, Yip BS, Chiou HY, Hsu CY. Get With the Guidelines-Stroke performance indicators: surveillance of stroke care in the Taiwan Stroke Registry: Get With the Guidelines-Stroke in Taiwan. Circulation. 2010 Sep 14;122(11):1116-23.

19. Fonarow Gregg C, Smith Eric E, Saver Jeffrey L, Reeves Mathew J, Hernandez Adrian F, Peterson Eric D, Sacco Ralph L, Schwamm Lee H. Improving Door-to-Needle Times in Acute Ischemic Stroke. Stroke. 2011 2011/10/01 [cited 2018/11/17];42(10):2983-2989. 
20. Bettger JP, Li Z, Xian Y, Liu L, Zhao X, Li H, Wang C, Wang C, Meng X, Wang A, Pan Y, Peterson ED, Wang Y, Wang Y. Assessment and provision of rehabilitation among patients hospitalized with acute ischemic stroke in China: Findings from the China National Stroke Registry II. International Journal of Stroke. 2017 2017/04/01 [cited 2018/12/02];12(3):254-263. 21. Pham TL, Blizzard L, Srikanth V, Thrift AG, Lien NT, Thang NH, Gall SL. Case-fatality and functional status three months after first-ever stroke in Vietnam. J Neurol Sci. 2016 Jun $15 ; 365: 65-71$.

22. Tirschwell DL, Ton TG, Ly KA, Van Ngo Q, Vo TT, Pham CH, Longstreth WT, Jr., Fitzpatrick AL. A prospective cohort study of stroke characteristics, care, and mortality in a hospital stroke registry in Vietnam. BMC Neurol. 2012 Dec 3;12:150.

23. Banna MA, Baldawi H, Kadhim A, Humaidan H, Whitford DL. Stroke in Bahrain: Rising Incidence, Multiple Risk Factors, and Suboptimal Care. International Journal of Stroke. 2015 2015/06/01 [cited 2018/12/03];10(4):615-618.

24. Nazifah SN, Azmi IK, Hamidon BB, Looi I, Zariah AA, Hanip MR. National Stroke Registry (NSR): Terengganu and Seberang Jaya experience. Med J Malaysia. 2012 Jun;67(3):302-4.

25. Pham T. Occurrence, presentation, costs and three-month outcomes of stroke in Viet Nam: University of Tasmania [Doctoral thesis]; 2015.

26. Trung Quang Vo HTTT, Nam Phuong Nguyen, Ha Thi Song Nguyen, Thuy Van Ha, Nghiem Quan Le. Economic Aspects of Post-Stroke Rehabilitation: A Retrospective Data at a Traditional Medicine Hospital in Vietnam. Journal of Clinical and Diagnostic Research. 2018 March 13 2019;12(6):LC05-LC10. 
27. Yamanashi H, Ngoc MQ, Huy TV, Suzuki M, Tsujino A, Toizumi M, Takahashi K, Thiem VD, Anh DD, Anh NTH, Tho LH, Maeda T, Cox SE, Yoshida L-M, Ariyoshi K. PopulationBased Incidence Rates of First-Ever Stroke in Central Vietnam. PLOS ONE. 2016;11(8):e0160665.

28. Phan HT, Blizzard CL, Reeves MJ, Thrift AG, Cadilhac D, Sturm J, Heeley E, Otahal P, Konstantinos V, Anderson C, Parmar P, Krishnamurthi R, Barker-Collo S, Feigin V, Bejot Y, Cabral NL, Carolei A, Sacco S, Chausson N, Olindo S, Rothwell P, Silva C, Correia M, Magalhaes R, Appelros P, Korv J, Vibo R, Minelli C, Gall S. Sex Differences in Long-Term Mortality After Stroke in the INSTRUCT (INternational STRoke oUtComes sTudy): A MetaAnalysis of Individual Participant Data. Circ Cardiovasc Qual Outcomes. 2017 Feb;10(2).

29. Nguyen TH, Truong AL, Ngo MB, Bui CT, Dinh QV, Doan TC, Nguyen LT, Phan TC, Phan MV, Nguyen TV, Le TV. Patients with thrombolysed stroke in Vietnam have an excellent outcome: results from the Vietnam Thrombolysis Registry. Eur J Neurol. 2010 Sep;17(9):118892.

30. Registry of Stroke Care Quality. RES-Q December 2018 Update. Geneva, Switzerland: World Stroke Organization; 2018. Available from: https://www.qualityregistry.eu/images/updates/RESQ_December_2018_update_formatted.pdf 31. Registry of Stroke Care Quality. RES-Q Live Metrics. Geneva, Switzerland: World Stroke Organization; 2018 [cited 201920 April]. Available from: https://qualityregistry.eu/mbaux/public/dashboard/78a1e97d-fe82-4aad-a229-f3044e9999d7

32. Lutsenko I, Sultanova A. Implementation and the first results of the Stroke Quality Registry RES-Q in Bishkek, Kyrgyzstan. World Stroke Congress 2018 Montreal, Canada. Int J Stroke; 2018 p. 193 
33. Grecu A, Simsic S, Jankujova M, Mikulik R. Improvements to the Registry for Stroke Care Quality (RES-Q) based on first year user feedback. European Stroke Organisation Conference 2018 Gothenburg, Sweden. Eur Stroke J; 2018 p. 290

34. Tinh D. Ho Chi Minh City Department of Health announces hospital 'rankings'. Ho Chi Minh City: Tien Phong; 2019 [cited 201925 Jan]. Available from:

https://www.tienphong.vn/suc-khoe/so-y-te-tphcm-cong-bo-bang-xep-hang-benh-vien1366146.tpo

35. Phan HT, Blizzard CL, Reeves MJ, Thrift AG, Cadilhac D, Sturm J, Heeley E, Otahal P, Konstantinos V, Anderson C, Parmar P, Krishnamurthi R, Barker-Collo S, Feigin V, Bejot Y, Cabral NL, Carolei A, Sacco S, Chausson N, Olindo S, Rothwell P, Silva C, Correia M, Magalhães R, Appelros P, Kõrv J, Vibo R, Minelli C, Gall S. Sex differences in long-term mortality after stroke in the INSTRUCT (INternational STRoke oUtComes sTudy). A metaanalysis of individual participant data. Circ Cardiovasc Qual Outcomes. 2017;10(2):e003436. 36. Jha P. Reliable direct measurement of causes of death in low- and middle-income countries. BMC Medicine. 201404 Feb;12:19-19. Available from: PMC 
Table 1. Characteristic of RES-Q registrants for stroke in the stroke unit in 115 People's Hospital during June 2017-July 2018 by sex

$$
\mathrm{n}(\%) \text { or median (IQR) }
$$

\begin{tabular}{|c|c|c|c|c|}
\hline & Overall & Men & Women & $\mathrm{P}-$ value* \\
\hline Number of cases & 6,601 & $3,695(56.0)$ & $2,906(44.0)$ & $<0.001$ \\
\hline \multicolumn{5}{|l|}{ Sociodemographics } \\
\hline Age, median (IQR) & $62(53-72)$ & $60(52-69)$ & $65(56-75)$ & $<0.001$ \\
\hline \multicolumn{5}{|l|}{ Pre-stroke health } \\
\hline Current smoker & $2,779(42.1)$ & $2,324(62.9)$ & $455(15.7)$ & $<0.001$ \\
\hline \multicolumn{5}{|l|}{ The presence of AF } \\
\hline Detected by screening & $630(9.5)$ & $284(7.7)$ & $346(11.9)$ & $<0.001$ \\
\hline Undetected by screening & $99(1.5)$ & $39(1.1)$ & $60(2.1)$ & \\
\hline Unscreened & $5,872(90.0)$ & $3,372(91.3)$ & $2,500(86.0)$ & \\
\hline \multicolumn{5}{|l|}{ Stroke-related factors } \\
\hline \multicolumn{5}{|l|}{ Stroke severity } \\
\hline NIHSS, median (IQR)* & $7(4-12)$ & $7(4-11)$ & $7(4-12)$ & 0.100 \\
\hline $\begin{array}{l}\text { Loss of consciousness } \\
\text { (drowsy/comatose) }\end{array}$ & $569(8.8)$ & $313(8.6)$ & $256(8.9)$ & 0.671 \\
\hline In-hospital stroke & $34(0.5)$ & $17(0.5)$ & $17(0.6)$ & 0.482 \\
\hline \multicolumn{5}{|l|}{ Type of stroke } \\
\hline Ischemic stroke (IS) & $5274(79.9)$ & $2911(78.8)$ & $2363(81.3)$ & 0.023 \\
\hline $\begin{array}{l}\text { Intracerebral hemorrhagic } \\
\text { (ICH) }\end{array}$ & $1,217(18.4)$ & $714(19.3)$ & $503(17.3)$ & \\
\hline $\begin{array}{l}\text { Subarachnoid } \\
\text { hemorrhagic }\end{array}$ & $110(1.7)$ & $70(1.9)$ & $40(1.4)$ & \\
\hline \multicolumn{5}{|l|}{ Processes of care } \\
\hline $\begin{array}{l}\text { Median time to hospital } \\
\text { (hours) }\end{array}$ & $15.7(5.6-37.5)$ & $14.2(5.4-35.0)$ & $18.5(5.9-44.0)$ & 0.827 \\
\hline \multicolumn{5}{|l|}{ Time to hospital } \\
\hline$\leq 3.5$ hours & $794(12.0)$ & $465(12.6)$ & $329(11.3)$ & 0.088 \\
\hline$>3.5$ hours & $4,670(70.8)$ & $2,583(69.9)$ & $2,087(71.8)$ & \\
\hline Missing & $1,137(17.2)$ & $647(17.5)$ & $490(16.9)$ & \\
\hline Neuroimaging & $6,497(98.4)$ & $3,695(98.5)$ & $2,858(98.4)$ & 0.659 \\
\hline $\begin{array}{l}\text { Carotid investigation } \leq 7 \\
\text { days after hospital } \\
\text { admission (IS) }\end{array}$ & 257 (4.9) & $126(4.3)$ & $131(5.5)$ & 0.041 \\
\hline $\begin{array}{l}\text { Carotid endarterectomy or } \\
\text { angioplasty/stenting } \leq 2 \\
\text { weeks after stroke onset } \\
\text { (IS) }\end{array}$ & $30(8.7)$ & $20(8.1)$ & $10(10.2)$ & 0.531 \\
\hline $\begin{array}{l}\text { Intravenous thrombolysis } \\
\text { (tPA; all cases) }\end{array}$ & $497(7.5 \%)$ & $290(7.9)$ & $207(7.1)$ & 0.268 \\
\hline $\begin{array}{l}\text { Intravenous thrombolysis } \\
\text { (tPA; IS and admission } \\
\text { time } \leq 3.5 \text { hours) }\end{array}$ & $497(9.4 \%)$ & $290(10.0)$ & $207(8.8)$ & 0.137 \\
\hline $\begin{array}{l}\text { Recanalization procedures } \\
\text { (IS) }\end{array}$ & 611 (11.6) & $349(12.0)$ & $262(11.0)$ & 0.309 \\
\hline tPA alone & $377(7.2)$ & & & \\
\hline
\end{tabular}




\begin{tabular}{|c|c|c|c|c|}
\hline \multirow{4}{*}{$\begin{array}{l}\text { tPA }+ \text { endovascular } \\
\text { treatment } \\
\text { endovascular treatment } \\
\text { alone } \\
\text { No }\end{array}$} & \multirow{2}{*}{\multicolumn{4}{|c|}{$120(2.2)$}} \\
\hline & & & & \\
\hline & \multicolumn{4}{|l|}{$114(2.2)$} \\
\hline & \multicolumn{4}{|l|}{$4,633(88.4)$} \\
\hline \multicolumn{2}{|c|}{ Time to needle (mins, IQR) $45(33-60)$} & $45(30-60)$ & $45(34-60)$ & 1.000 \\
\hline \multicolumn{5}{|l|}{$\begin{array}{l}\text { rehabilitation needs } \leq 72 \\
\text { hours after hospital } \\
\text { admission }\end{array}$} \\
\hline \multicolumn{5}{|l|}{$(\mathrm{ICH})$} \\
\hline Hemicraniectomy (ICH) & $30(8.7)$ & $20(8.1)$ & $10(10.2)$ & 0.531 \\
\hline Dysphagia screening & $6,565(99.5)$ & $3,672(99.4)$ & $2,893(99.6)$ & 0.338 \\
\hline Dysphagia screening (IS) & $5,241(99.4)$ & $2,980(99.3)$ & $2,351(99.5)$ & 0.328 \\
\hline Antihypertensive agent $\uparrow$ & $5,902(92.2)$ & $3,299(91.8)$ & $2,603(92.7)$ & 0.179 \\
\hline $\begin{array}{l}\text { Cholesterol-lowering } \\
\text { medication } \dagger\end{array}$ & $5,071(79.2)$ & $2,808(78.1)$ & $2,263(80.6)$ & 0.016 \\
\hline $\begin{array}{l}\text { Cholesterol-lowering } \\
\text { medication (IS) } \dagger\end{array}$ & $5,071(99.0)$ & $2,808(99.0)$ & $2,263(99.0)$ & 0.954 \\
\hline \multicolumn{2}{|l|}{$(\mathrm{IS}) \dagger$} & $2,771(97.7)$ & $2,245(98.2)$ & 0.185 \\
\hline \multicolumn{5}{|l|}{ Discharge information } \\
\hline $\begin{array}{l}\text { LOS if discharged, median } \\
\text { (IQR) }\end{array}$ & $3(1-6)$ & $3(1-5)$ & $3(1-7)$ & 0.781 \\
\hline $\begin{array}{l}\text { LOS if deceased, median } \\
\text { (IQR) }\end{array}$ & $4(3-6)$ & $4(3-6)$ & $4(3-6)$ & 0.100 \\
\hline \multicolumn{5}{|l|}{ Discharge destination } \\
\hline Home & $5,869(88.9)$ & $3,275(88.6)$ & $2,594(89.2)$ & 0.139 \\
\hline Rehabilitation facility & $334(5.1)$ & $197(5.3)$ & $137(4.7)$ & \\
\hline $\begin{array}{l}\text { Long-term care } \\
\text { facility/nursing home }\end{array}$ & $66(1.0)$ & $44(1.2)$ & $22(0.8)$ & \\
\hline Other hospital & $133(2.0)$ & $78(2.1)$ & $55(1.9)$ & \\
\hline Died & $199(3.1)$ & $101(2.7)$ & $98(3.4)$ & \\
\hline $\begin{array}{l}\text { Able to walk } 10 \text { meters } \\
\text { without assistance } \dagger\end{array}$ & $2,931(45.8)$ & $1,688(47.0)$ & $1,243(44.3)$ & 0.031 \\
\hline
\end{tabular}

Length of stay: LOS. IQR: Interquartile range. Of note, missing data on processes of care were coded as not receiving the corresponding therapy

*missing data $<10 \%$

famong those discharged 
Table 2. Predictors of outcomes at discharge in univariable and multivariable models*

\begin{tabular}{|c|c|c|c|c|}
\hline \multirow[t]{2}{*}{ Covariate } & \multicolumn{2}{|c|}{ In-hospital mortality } & \multicolumn{2}{|c|}{ Poorer functional outcome } \\
\hline & $\begin{array}{l}\text { Univariable } \\
\text { model } \\
\text { RR }(95 \% \mathrm{CI})\end{array}$ & $\begin{array}{l}\text { Multivariable } \\
\text { model } \\
\text { RR }(95 \% \mathrm{CI})\end{array}$ & $\begin{array}{l}\text { Univariable } \\
\text { model } \\
\text { RR }(95 \% \mathrm{CI})\end{array}$ & $\begin{array}{l}\text { Multivariable } \\
\text { model } \\
\text { RR }(95 \% \mathrm{CI})\end{array}$ \\
\hline \multicolumn{5}{|l|}{$\begin{array}{l}\text { Model } 1 \text { (All } \\
\text { strokes) }\end{array}$} \\
\hline Age & $\begin{array}{l}1.04(1.03- \\
1.05)\end{array}$ & $\begin{array}{l}1.02(1.01- \\
1.03)\end{array}$ & $\begin{array}{l}1.01(1.00- \\
1.01)\end{array}$ & $\begin{array}{l}1.00(1.00- \\
1.01)\end{array}$ \\
\hline NIHSS & $\begin{array}{l}1.18(1.16- \\
1.20)\end{array}$ & $\begin{array}{l}1.10(1.08- \\
1.12)\end{array}$ & $\begin{array}{l}1.08(1.08- \\
1.09)\end{array}$ & $\begin{array}{l}1.08(1.08- \\
1.09)\end{array}$ \\
\hline $\begin{array}{l}\text { Antihypertensive } \\
\text { agent(s) }\end{array}$ & $\begin{array}{l}0.01(0.01- \\
0.02)\end{array}$ & $\begin{array}{l}0.02(0.01- \\
0.04)\end{array}$ & $\begin{array}{l}1.13(0.99- \\
1.28)\end{array}$ & $\begin{array}{l}1.14(1.00- \\
1.31)\end{array}$ \\
\hline \multicolumn{5}{|l|}{$\begin{array}{l}\text { Model } 2 \text { (Ischemic } \\
\text { strokes) }\end{array}$} \\
\hline Age & $\begin{array}{l}1.05(1.03- \\
1.07)\end{array}$ & ns & $\begin{array}{l}1.01(1.00- \\
1.01)\end{array}$ & $\begin{array}{l}1.01(1.00- \\
1.01)\end{array}$ \\
\hline NIHSS & $\begin{array}{l}1.18(1.16- \\
1.20)\end{array}$ & ns & $\begin{array}{l}1.08(1.08- \\
1.09)\end{array}$ & $\begin{array}{l}1.08(1.08- \\
1.09)\end{array}$ \\
\hline $\begin{array}{l}\text { Antihypertensive } \\
\text { agent(s) }\end{array}$ & $\begin{array}{l}0.01(0.006- \\
0.02)\end{array}$ & $\begin{array}{l}0.30(0.14- \\
0.63)\end{array}$ & $\begin{array}{l}1.02(0.89- \\
1.17)\end{array}$ & ns \\
\hline $\begin{array}{l}\text { Cholesterol-lowering } \\
\text { medication }\end{array}$ & $\begin{array}{l}0.002(0.001- \\
0.004)\end{array}$ & $\begin{array}{l}0.02(0.006- \\
0.06)\end{array}$ & $\begin{array}{l}0.66(0.49- \\
0.91)\end{array}$ & ns \\
\hline $\begin{array}{l}\text { Antithrombotic } \\
\text { medication }\end{array}$ & $\begin{array}{l}0.004(0.002- \\
0.007)\end{array}$ & $\begin{array}{l}0.23(0.09- \\
0.61)\end{array}$ & $\begin{array}{l}0.67(0.53- \\
0.83)\end{array}$ & ns \\
\hline
\end{tabular}

RR: relative risk; CI: confidence interval; not significant; NIHSS: National Institute of Health Stroke Scale, ns: not statistically significant $(\mathrm{p}<0.05)$

*Only significant variables $(\mathrm{p}<0.05)$ were retained in the multivariable models 


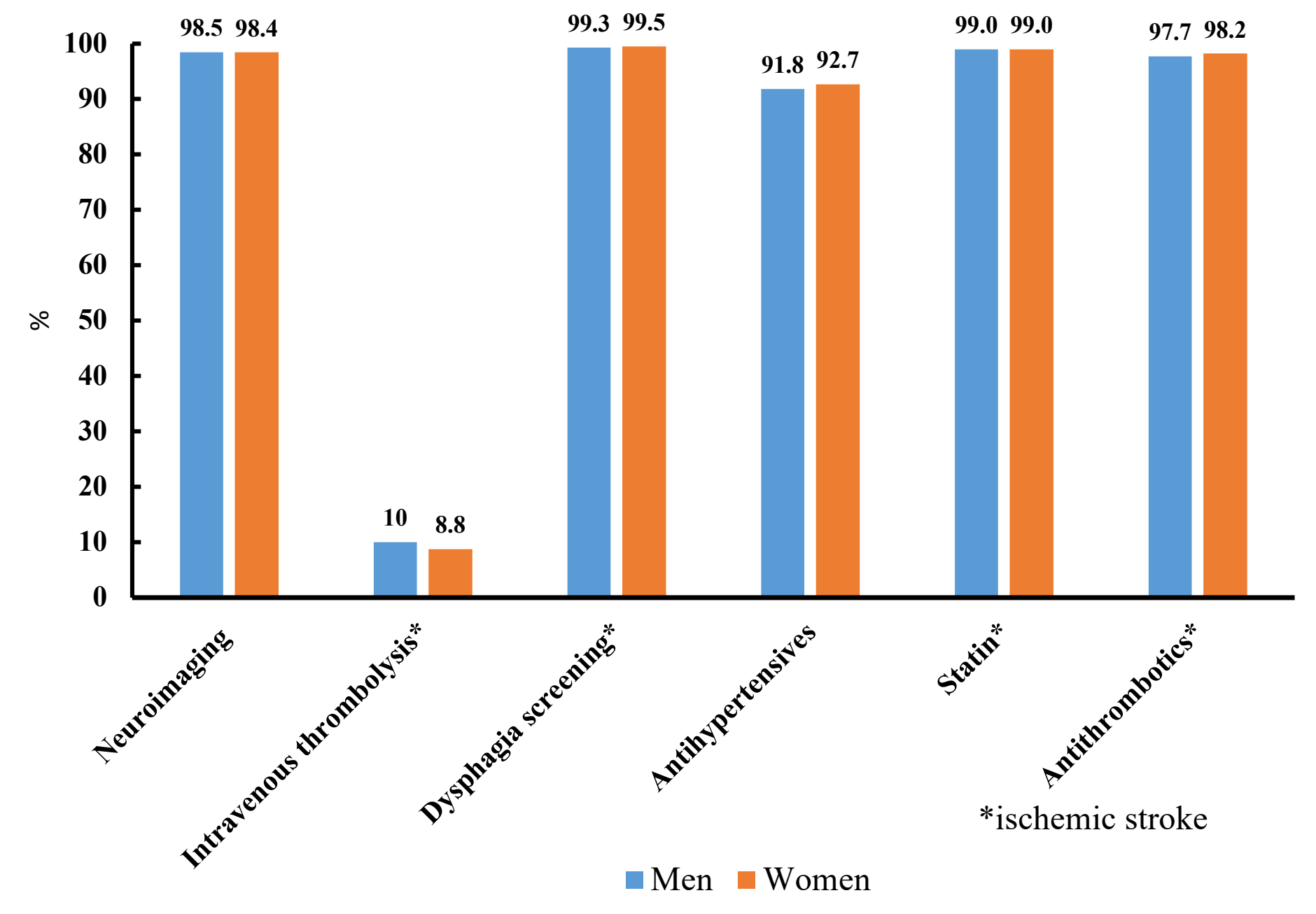

Figure 1. Evidence-based care received in the stroke unit in 115 People's Hospital among hospitalized patients with acute stroke during Jun 2017 and Mar 2018 registered in the RES-Q 
Table 3. Characteristic of RES-Q registrants for stroke in the 115 People's Hospital compared with other stroke registries from selected low- and middle-income countries

\begin{tabular}{llllll}
$\begin{array}{l}\text { RES-Q } \\
\text { Vietnam } \\
(\mathrm{n}=6,601)\end{array}$ & $\begin{array}{l}\text { Thai Stroke } \\
\text { Registry }^{1} \\
(\mathrm{n}=1,222)\end{array}$ & $\begin{array}{l}\text { China Stroke } \\
\text { Registry II } \\
(\mathrm{n}=19,294)\end{array}$ & $\begin{array}{l}\text { Bahrain }^{3} \\
(\mathrm{n}=521)\end{array}$ & $\begin{array}{l}\text { National Stroke } \\
\text { Registry (Malaysia; } \\
\mathrm{n}=1,018)^{4}\end{array}$ & $\begin{array}{l}\text { Taiwan Stroke Registry } \\
(\mathrm{n}=30,599)\end{array}$ \\
\hline Jun 17-Jul 18 & Jun 08 - Nov & Jun 12- Jan 13 & 2011 & Aug 09-Dec 10 & 06-08
\end{tabular}

\begin{tabular}{|c|c|c|c|c|c|c|}
\hline Year & Jun 17-Jul 18 & $\begin{array}{l}\text { Jun } 08-\text { Nov } \\
10\end{array}$ & Jun $12-$ Jan 13 & 2011 & Aug $09-$ Dec 10 & $06-08$ \\
\hline$\overline{\text { Women (\%) }}$ & 44 & 45 & 37 & 34 & 46 & 40 \\
\hline \multicolumn{7}{|l|}{ Sociodemographics } \\
\hline $\begin{array}{l}\text { Age, median (IQR); or } \\
\text { mean (SD) }\end{array}$ & $62(53-72)$ & $\begin{array}{l}\text { mean: } 65.0 \\
(13.0)\end{array}$ & $65(57-74)$ & $\begin{array}{l}\text { mean: } 60.5 \\
\text { (na) }\end{array}$ & mean: $62.5(\mathrm{na})$ & $70(60-78) \dagger$ \\
\hline \multicolumn{7}{|l|}{ Pre-stroke health } \\
\hline Current smoker (\%) & 42.1 & & 44.2 & & & $40.4 \dagger$ \\
\hline Atrial fibrillation (AF; \%) & 9.5 & & 7.1 & & & $16.5 \dagger$ \\
\hline \multicolumn{7}{|c|}{ Stroke-related factors } \\
\hline \multicolumn{7}{|l|}{ Stroke severity } \\
\hline NIHSS, median (IQR)* & $7(4-12)$ & $6.5(3-12)$ & $4(2-7)$ & & & $5(2-9) \dagger$ \\
\hline $\begin{array}{l}\text { Loss of consciousness } \\
\text { (drowsy/comatose; \%) }\end{array}$ & 8.8 & & & 32.6 & & \\
\hline \multicolumn{7}{|l|}{ Type of stroke $(\%)$} \\
\hline Ischemic stroke (IS) & 79.9 & 100 & 100 & 60.0 & 73.3 & 74.0 \\
\hline $\begin{array}{l}\text { Intracerebral } \\
\text { hemorrhagic (ICH) }\end{array}$ & 18.4 & excluded & excluded & 20.0 & 20.9 & 16.1 \\
\hline $\begin{array}{l}\text { Subarachnoid } \\
\text { hemorrhagic }\end{array}$ & 1.7 & excluded & excluded & 3.0 & 1.7 & 2.8 \\
\hline \multicolumn{7}{|l|}{ Processes of care $(\%)$} \\
\hline Neuroimaging & 98.4 & 100 & & 88.2 & & $92.1 \dagger$ \\
\hline Stroke unit access & 100.0 & 24.6 & & & & \\
\hline $\begin{array}{l}\text { Carotid imaging before } \\
\text { discharge (IS) }\end{array}$ & 4.9 ( $\leq 7$ days $)$ & 13.1 & 67.0 & 34.7 & & \\
\hline $\begin{array}{l}\text { Intravenous thrombolysis } \\
\text { (IS; \%) }\end{array}$ & 9.4 & 3.8 & & & & 8.8 \\
\hline
\end{tabular}


Assessment for

rehabilitation needs $\leq 72$

hours after hospital

admission (\%)

Dysphagia screening

Antihypertensive agent* 92.2

Cholesterol-lowering $\quad 79.2$

medication*

Cholesterol-lowering $\quad 99.0$

medication* (IS)

Antithrombotic

medication (IS)*

Aspirin administration $\leq 48$

hours

Antiplatelet agent(s) at

discharge

Anticoagulants if AF

\section{Discharge information}

Length of stay, median

$4(3-6)$

(IQR)

Length of stay, mean (SD)

In-hospital mortality (\%) 3.1

na: not available: SD: standard

*among those discharged

tamong IS
99.5

64.8 (before

discharge)

84.4

31.0

73.4

65.9
80.1

39.8

$4(3-7)$
52.8

$20.3(\leq 24 \quad 83.0$

hours)

79.0

$82.0 \quad 87.0$

83.0

38.6

38.7

94.1

82.3

85.7

84.4

85.5

39.4

$13(9-16)$

$8(5-15) \dagger$

$15.4(?) \quad 5.1(?)$

$13.4 \quad 11.1 \quad 4.0 \dagger$ 


\section{References}

1. Nilanont Y, Nidhinandana S, Suwanwela NC, Hanchaiphiboolkul S, Pimpak T, Tatsanavivat P, et al. Quality of acute ischemic stroke care in Thailand: a prospective multicenter countrywide cohort study. J Stroke Cerebrovasc Dis. 2014 Feb;23(2):213-9.

2. Bettger JP, Li Z, Xian Y, Liu L, Zhao X, Li H, et al. Assessment and provision of rehabilitation among patients hospitalized with acute ischemic stroke in China: Findings from the China National Stroke Registry II. International Journal of Stroke. 2017 2017/04/01 [cited 2018/12/02];12(3):254-263.

3. Banna MA, Baldawi H, Kadhim A, Humaidan H, Whitford DL. Stroke in Bahrain: Rising Incidence, Multiple Risk Factors, and Suboptimal Care. International Journal of Stroke. 2015 2015/06/01 [cited 2018/12/03];10(4):615-618.

4. Nazifah SN, Azmi IK, Hamidon BB, Looi I, Zariah AA, Hanip MR. National Stroke Registry (NSR): Terengganu and Seberang Jaya experience. Med J Malaysia. 2012 Jun;67(3):302-4.

5. Hsieh FI, Lien LM, Chen ST, Bai CH, Sun MC, Tseng HP, et al. Get With the Guidelines-Stroke performance indicators: surveillance of stroke care in the Taiwan Stroke Registry: Get With the Guidelines-Stroke in Taiwan. Circulation. 2010 Sep 14;122(11):1116-23. 